\title{
VOC Emissions From Wood Products and Furniture: a Survey About Legislation, Standards and Measures Referred to Different Materials
}

Franco Bulian

Vice-Director Catas Spa

Italy

Cristiano Fragassa

Assistant Professor University of Bologna Departmet of Industrial Engineering
The health and safety of people in indoor environments are influenced not only by climate and biological agents (bacteria, virus) but also by the potential presence of air pollutants. Pollutants can come from many sources, such as cigarette smoke, fireplaces, preparation of foods, traffic, etc. Even furniture and building materials used in constructions (floorings, ceilings, walls, etc.) can emit harmful substances for the health of the occupants. Such emissions mainly derive from the coatings applied on the surfaces of the finished products and consequently a special attention shall be paid to the formulation and to the use of such products. This paper presents a summary about the legislative and normative scenario on indoor emissions with the evidence of some data referred to parquet floorings coated with different coating materials. The work, as well as recalling the concepts expressed above, represents a point of reference on the subject for all operators in the sector given the innovative nature and however strong impact that the VOC issue currently plays in this area.

Keywords: VOC, regulations, voluntary certifications, indoor emissions, parquet floorings,

\section{INTRODUCTION}

Every human roughly inspires 5 million litres of air every year being mainly composed, as it is well-known, of nitrogen and oxygen. Nevertheless, it is possible to estimate that around 50000 litres of other gases (carbon dioxide, argon, etc.) are introduced in our organism every year with potential effects on our metabolism depending on their composition. As the majority of the human life is spent inside buildings (houses, offices, schools, hospitals and so on) a particular attention to the indoor air quality should be consequently paid.

Formaldehyde is certainly the best-known example of a potentially dangerous substance that can be released from the materials present inside houses, offices, schools and other indoor living environments. Test methods and limits for this substance had already been developed, allowing the market to verify the conformity of raw materials and finished products [1].

Nevertheless, formaldehyde is not the only substance that can be emitted from furniture or construction products as the materials with which they are made of can contain several other volatile compounds. These substances tend, during time, to gradually be released in the environment in which finished products are placed.

There are also other compounds that can result from microbiological activity (MVOC) or special treatments

Received: May 2016, Accepted: June 2016

Correspondence to: Dr Franco Bulian

CATAS - Via Antica 24/3

33048, San Giovanni al Natisone (UD). Italy

E-mail: bulan@catas.com

doi:10.5937/fmet1604358B

(c) Faculty of Mechanical Engineering, Belgrade. All rights reserved applied to the wood surface (e.g. ammonia).

All of these substances may have a negative impact on air quality and consequently on the health of the users living in indoor environments where they are present.

The knowledge of VOC emissions from finished products and their control is becoming a particularly sensitive subject for the market because of the increased attention to the safety of finished products mentioned above [2].

Moreover the increasing need of energy saving buildings determines a considerable evolution in insulating systems and devices reducing, on the other side, the air exchange in houses, offices schools and so on, with a potential increase of the concentration of polluting substances in indoor air.

At EU level, following the publication of the EU regulation n.305/2011 including indoor emissions among the essential requirements for construction products, the technical committee TC351 of CEN is responsible for establishing test methods and limits for harmful substances released from building materials.

Two Member States, France [3] and Germany [4], have recently published specific regulations on this matter that producers must know and respect in order to freely export their products. Also, Belgium is going to publish a similar law coming in to force in 2014 [5].

A number of national and industry voluntary labelling schemes for low emitting products also exist in Europe and each has its own specific requirements for testing and product evaluation.

This complex situation results in significant costs to manufacturers exporting their products in different European markets and is also potentially confusing for consumers wishing to make clear and objective choices. 
This paper will try to summarize the complex situation of VOC emissions from wood products and furniture in EU. This survey contains references to national laws, standards and voluntary certifications. One of the goals is to show the different approaches with explanations about definitions and criteria used.

As coating materials applied on finished products are the main source of indoor emissions, this paper also contains some data derived from laboratory experiments carried out on different coating systems with some indications about their possible emissions in indoor environments.

The final aim is to give to the market a simple guideline to approach this new and complex scenario.

\section{SUBSTANCES POTENTIALLY EMITTED FROM FINISHED PRODUCTS}

Many different volatile substances can be emitted from furniture and construction products.

Formaldehyde represents a particular case as it mainly derives from the hydrolysis of the ureaformaldehyde adhesives used for the production of wood based panels like particleboards, fibreboards and plywoods.

Hydrolysis is a continuous process caused by the presence of moisture and accelerated by temperature. Consequently, formaldehyde emission is a never-ending process as this substance is continuously generated inside panels.

On the contrary, the emission of other volatile organic compounds is the process tending to decrease and terminate during time, as they are not produced inside the materials. Such emissions are mainly due to coatings applied to the surfaces of walls, floorings, doors, furniture and so on. Organic solvents and other volatile substances present in the coating formulation do not completely evaporate during drying and consequently they slowly evaporate inside the buildings where the final product is placed.

Apart from formaldehyde, the other compounds that can be emitted from the materials are normally classified as:

- VOCs: volatile organic compounds.

- VVOC: very volatile organic compounds, normally low boiling point solvents, which are rapidly released after the installation of a material or a finished product.

- SVOC: Semi-volatile organic compounds, which can be particularly persistent, being slowly released over time. They are typically high-boiling point solvents, coalescents or natural substances derived from terpene-based treatments like turpentine.

\subsection{Measuring methods}

The international reference test method for measuring VOC emissions from raw materials and finished products is defined by the standard EN ISO 160009:2006 Determination of the emission of volatile organic compounds from building products and furnishing - Emission test chamber method.

This method consists of an empty chamber of different volume (normally from $0.1 \mathrm{~m}^{3}$ to $40 \mathrm{~m}^{3}$ ) with internal conditions similar to those normally found in living indoor environments $\left(23^{\circ} \mathrm{C}, 50 \%\right.$ r.h., 0.5 air exchanges/hour).

The sample is placed inside the chamber with a surface area normally corresponding to the real situations. The air inside the chamber is continuously mixed and sampled at regular intervals (usually after 72 hours and 28 days). The qualitative and quantitative analysis is then performed by a gaschromatograph coupled with a Mass Spectrometer detector because of its high sensitivity and analytical specificity.

It shall be considered here that the working group 2 (WG2) of CEN committee 351 has defined a new method (presently in the form of Technical Specification CEN/TS 16516), based on the above mentioned ISO standard, to be specific for the CE marking inside the EU.

Another method, to be necessarily mentioned, is the EN 16402 Paints and varnishes - Assessment of emissions of substances from coatings into indoor air Sampling, conditioning and testing developed by CEN TC139 to be used to assess the VOC emissions from applied coatings. The latter standard is also based on the basic principles of EN ISO 16000, but it contains specific instructions to deal with liquid coating materials.

\subsection{Health evaluation}

Unfortunately, science has not yet been able to elucidate the mechanisms causing a negative effect on health in the exposure conditions of indoor environments [2] for the majority of substances. A lot of data is presently available only for substances in the workplaces but sufficient data to enable a full risk assessment in indoor places exists only for a few substances.

One of the main differences with workplaces is the evidence that the period of time to which the population is exposed to indoor pollution is considerably longer. Moreover, the healthy conditions of the people involved can be totally different: infants, elderly people and persons with disabilities (asthmatics, allergic, convalescents and so on) shall be then considered in the definition of the exposure limits.

Another difference in the case of indoor pollution is that health cannot just be considered as an absence of illnesses, but it shall be also related to the term "comfort". Consequently, it will not be enough to reduce the exposure to the healthy-related substances, but the overall effects from other substances need to be reduced as well. These considerations lead to the development of a complex criteria to fix limits for indoor pollution based of different parameters which normally are even combined together.

\subsection{Carcinogen substances}

In spite of a few exceptions, there are usually no safe limit values for carcinogenic substances, even the smallest amounts of carcinogens can, in theory, cause cancer mutations in cells. Therefore, the usual practice to fix very low limits for the amount of carcinogens (Cat. 1 and 2 according to EU-carcinogens classifi- 
cation). In emission testing of indoor products, if carcinogens are detected after 3 days, the test shall be considered "negative" and stopped. Such criteria normally incorporate also Mutagens (substances able to modify the DNA thus increasing the risk of cancer) and Reprotoxic (substances causing abnormal prenatal development resulting in birth defects).

\subsection{Lowest Concentration of Interest ( $\mathrm{LCl})$}

The LCI (Lowest Concentration of Interest) approach is currently the most feasible strategy to esthablish reference values refferring to the potential health effects of individual compounds emitted from raw materials and finished products.

The harmonisation process of LCI values has recently started in Europe (EU-LCI project led by the European Commission's Joint Research Centre on behalf of the Directorate General for Health \& Consumer (DG SANCO) [2].

The definition of the LCI limits is based on different criteria such as, for example, the use of the workplaces exposure limits divided by safety indexes (e.g. 100 for common substances and 1000 for the toxic ones).

LCI's are limits for the single substances but, as in the case of the German law, also the sum of all the concentrations of the substances with a defined LCI has to be considered (e.g. $\sum$ (Ci/LCIi $\leq 1$ where $\mathrm{Ci}$ is the concentration of each singe substance).

Criteria are also set for substances for which LCI values are not already established. For example, the German specification prescribes a limit of $0.1 \mathrm{mg} / \mathrm{m}^{3}$ for the sum of all these VOCs.

\subsection{Total volatile organic compounds (TVOC)}

The sum of all VOC's, indicated as Total VOC (TVOC) is normally combined with the limitation of CMR (Carcinogenic, Mutagenic or Reprotoxic) substances and with the LCI concept. This general limit considers the potential "combination" effect of the presence of more substances in indoor air and their cumulative effect on the comfort of the people.

\subsection{Odour}

The indoor air consists of Nitrogen, Oxygen and many other substances in small quantities. As reported before, for many of them there is only limited data on their related health impact. The situation is further complicated by their possible interactions and it is consequently obvious that the current measurement methods can only reveal a part of the whole problem.

Moreover, humans are very sensitive to odours and our sensory system can detect them as pleasant (e.g. food) or bad. In this second case, odours can be frequently considered as warnings for health hazards.

The chemical characterisation of emissions is not always a good predictor of sensory effects [2]. Therefore, for the evaluation of the healthy and comfort of indoor environments, it is important to complement the chemical assessment with sensory evaluation.
The draft standard ISO/FDIS 16000-28 on the determination of odour emissions from building products using test chambers is expected to be published soon. It includes both intensity measurement and acceptability evaluations for odours.

\section{STANDARDISATION LEGISLATION AND VOLUNTARY CERTIFICATIONS}

\subsection{European Union}

The Construction Product Regulation (EU 2011/305) since 1st July 2013 defines the essential requirements for construction materials [6]. This Regulation replaces the directive 89/106/EEC. Among the seven requirements number three, already present in the old directive, is dedicated to: hygiene, health and environment. Then the regulation prescribes that any construction work shall not be harmful to the health of occupants, meaning that no dangerous particles or gases shall be emitted in the air.

The purpose of this regulation is to harmonize the technical and healthy description of products including also indoor emissions thus facilitating their marketing in the EU area. The goal is that the CE label applied on building materials and products will contain performance classes that cover all national regulations in Europe. Then each EU member state can specify which performance classes a product shall fulfil for being accepted on that national market. For indoor emissions and other types of releases, CEN has established a technical committee (TC 351) to undertake the work of developing the harmonised standards. A specific working group (WG 2) is dealing with indoor air. At the moment, WG2 has produced a test method (CEN/TS 16516) for indoor emissions based on the ISO 16000 series of standards concerning determination of emissions of VOCs from building products.

\subsection{Germany}

The German regulation on volatile substances emission from building materials has its origin in the European Directive 89/106/EEC for CE marking of construction products recently replaced by the Regulation 305/2011. As written above, the directive established that any construction product shall not be harmful to the occupants of a building with specific reference to substances potentially emitted in indoor air. As both EU documents do not detail this requirement with respect to emission limits, Germany decided to establish a special task force set up by government authorities that deal with H\&S. This working group, called $\mathrm{AgBB}$, has consequently defined a regulation, which sets test methods, limits and procedure of control for VOC emissions from building materials.

The consequence is that building materials (e.g. flooring) marketed in Germany, besides the CE mark, must be further approved by the DIBt (a technical body that deals with the German Federal Building) to be installed in German buildings.

The process of obtaining approval is called Allgemeine Bauaufsichtliche Zulassung (ABZ) and consists of two steps. 
The manufacturer must initially provide to DiBt all the technical data about the product including the complete chemical composition of the coating used.

The chemical composition is needed for the identification of the product excluding the presence of dangerous substances. If dangerous substances are present (e.g. carcinogens) the request is rejected.

Is the first step is passed, the process can proceed with an inspection to the production site followed by a test of VOC emission according to the standard EN ISO 16000-9.

Tests and inspections are conducted by an organization officially recognized and authorized by DIBt. If the two steps are all successful, products can be marked with a "U", which in German means "Übereinstimmung" 'compliance'.

The surveillance of the product is maintained during the following years.

The emissions of the sample is analysed within the test chamber (EN ISO 16000-9), after 3 days, and after 28 days. The requirements to be met are those of table 1 .

Table 1. The German limits on VOC emissions

\begin{tabular}{l|c}
\hline \multicolumn{1}{c|}{ Substance } & Limit \\
\hline Carcinogenic compounds (3 days) & $10 \mu \mathrm{g} / \mathrm{m}^{3}$ \\
Sum of all VOCs (3 days) & $10 \mathrm{mg} / \mathrm{m}^{3}$ \\
Carcinogenic compounds (28 days) & $1 \mu \mathrm{g} / \mathrm{m}^{3}$ \\
Sum of all VOCs (28 days) & $1 \mathrm{mg} / \mathrm{m}^{3}$ \\
$\mathrm{Ri}=\mathrm{C}_{\mathrm{i}} / \mathrm{LCI}_{\mathrm{i}}{ }^{*}$ & 1 \\
$\sum \mathrm{Ri}$ & 1 \\
Sum of all VOC without LCI & $0.1 \mathrm{mg} / \mathrm{m}^{3}$ \\
\hline
\end{tabular}

(*) The list of LCI is reported in the AGBB protocol

\subsection{France}

In 2007, the French Government launched a concerted action (so-called Le Grenelle Environnement) for the identification and improvement of key issues regarding environment and health. Le Grenelle Environnement (2007) defined very ambitious objectives for the building sector in terms of energy saving. Such programme involves also the definition of a mandatory labelling for VOC emissions from building products including the ban of carcinogenic, mutagenic and toxic for reproduction substances category 1 and 2 (according to $67 / 548 /$ CEE directive classification).

Such objective has been transposed into French regulation by Decree $n^{\circ} 2011-321$ (March 23 ${ }^{\text {th }}, 2011$ ) relating to the labelling of construction products, floorings, wall coverings, paints and varnishes regarding their volatile pollutant emissions.

The above mentioned Decree states that products may only be made available on the market (after the 1st January 2012) if they are accompanied by a label indicating their emission classes of volatile compounds.

The Order of April 19 $9^{\text {th }}, 2011$ defines the list of volatile compounds to be considered (10 individual substances and the sum of total VOCs (TVOC), four emissions classes ranging from $\mathrm{A}+$ (very low emissions) to $\mathrm{C}$ (high emissions), the format of the label to be placed on the product or on its packaging and the methods for the characterisation of emissions for control purposes.
The second point has been transposed into French regulation by an Order of April $30^{\text {th }}, 2009$ relating to the conditions of use of building and decoration products containing CMR (Carcinogenic, Mutagenic or Reprotoxic) compounds category 1 and 2 and an Order of May $28^{\text {th }}, 2009$ modifying the Order of April $30^{\text {th }}$, 2009. Those orders state that building and decoration products can be placed on the market if their emissions of CMR compounds are lower than $1 \mu \mathrm{g} / \mathrm{m}^{3}$ after 28 days according to ISO 16000 standards. CMR compounds concerned by these regulations are trichloroethylene, benzene, dibutyl phthalate and bis (2ethylhexyl) phthalate.

The ISO $16000-9$ test shall be carried out by a laboratory accreditated according to EN ISO 17025.

Table 2. The French limits on VOC emissions

\begin{tabular}{l|cccc}
\hline \multicolumn{1}{c|}{ Substance } & $\begin{array}{c}\text { Class C } \\
\left(\mu \mathrm{g} / \mathrm{m}^{3}\right)\end{array}$ & $\begin{array}{c}\text { Class B } \\
\left(\mu \mathrm{g} / \mathrm{m}^{3}\right)\end{array}$ & $\begin{array}{c}\text { Class A } \\
\left(\mu \mathrm{g} / \mathrm{m}^{3}\right)\end{array}$ & $\begin{array}{c}\text { Class A+ } \\
\left(\mu \mathrm{g} / \mathrm{m}^{3}\right)\end{array}$ \\
\hline Formaldehyde & $>120$ & $<120$ & $<60$ & $<10$ \\
Acetaldehyde & $>400$ & $<400$ & $<300$ & $<200$ \\
Toluene & $>600$ & $<600$ & $<450$ & $<300$ \\
Tetrachloroethylene & $>500$ & $<500$ & $<350$ & $<150$ \\
Xylene & $>400$ & $<400$ & $<300$ & $<200$ \\
Trimethyl benzene & $>2000$ & $<2000$ & $<1500$ & $<1000$ \\
Dichloro benzene & $>120$ & $<120$ & $<90$ & $<60$ \\
Ethyl benzene & $>1500$ & $<1500$ & $<1000$ & $<750$ \\
Butoxy ethanol & $>2000$ & $<2000$ & $<1500$ & $<1000$ \\
Styrene & $>500$ & $<500$ & $<350$ & $<250$ \\
COVT & $>2000$ & $<2000$ & $<1500$ & $<1000$ \\
\hline
\end{tabular}

\subsection{Belgium}

Belgium has also published in 2014 a National regulation for the indoor emission of covered construction products (covers floorings, floor coverings, floor coatings, underlays, flooring installation products adhesives, finishing, coatings).

Products consisting of $100 \%$ natural stone, ceramic, glass, or steel represent exemptions.

VOC emissions shall be assessed by a laboratory accredited according to EN ISO 17025. The method prescribed is the chamber test according to EN ISO 16000 until the method prepared by CEN/TC351 will be published.

Limits are established for specific substances and for the sum of total VOCs. Belgium has adopted also the LCI criteria prescribing to temporary use the German LCI values until the European will be published (JRC).

\section{Table 3. The Belgian limits on VOC emissions}

\begin{tabular}{l|c}
\hline \multicolumn{1}{c|}{ Substance } & Limit after 28 days $\left(\mathrm{mg} / \mathrm{m}^{3}\right)$ \\
\hline Formaldehyde & 0.1 \\
Acetaldehyde & 0.2 \\
Toluene & 0.3 \\
TVOC & 1 \\
TSVOC & 0.1 \\
Carcinogen substances & 0.001 \\
$\mathrm{R}=\sum(\mathrm{Ci} / \mathrm{LCi})$ & 1 \\
\hline
\end{tabular}

\subsection{Voluntary certifications and other prescriptions}

Some voluntary labelling schemes have been developed during the last 20 years. Some of them have been developed by individual retailers (e.g. IKEA [7]) and 
industrial associations both for marketing purposes and to set common development targets. Other schemes are proposed by governative authorities or certification bodies.

Labelling schemes have been particularly developed in North Countries (e.g. Finland [8] and Denmark [9]).

Specific references for furniture can be found the German Blaue Angel certification [10]. The regulation RAL-UZ 38, which must be satisfied the get such award, sets emission limit values as specified in the following Table 4.

Table 4. The limits of RAL UZ38

\begin{tabular}{l|c}
\hline \multicolumn{1}{c|}{ Substance } & Limit $\left(\mathrm{mg} / \mathrm{m}^{3}\right)$ \\
\hline Formaldehyde & $0.05 \mathrm{ppm}$ \\
$\begin{array}{l}\text { Organic compounds with a boiling } \\
\text { point between } 50{ }^{\circ} \mathrm{C} \text { and } 250{ }^{\circ} \mathrm{C}\end{array}$ & $600 \mu \mathrm{g} / \mathrm{m}^{3}$ \\
$\begin{array}{l}\text { Organic compounds with a boiling } \\
\text { point higher than } 250{ }^{\circ} \mathrm{C}\end{array}$ & $100 \mu \mathrm{g} / \mathrm{m}^{3}$ \\
CMR & $<1 \mu \mathrm{g} / \mathrm{m}^{3}$ \\
\hline
\end{tabular}

Other limits for VOC emissions are also present in some international certifications schemes that apply to both individual components and complete buildings as: Leed, Greenguard, OSPAR and California Proposition 65.

The Italian CONSIP, a governative company which activity is related to public procurement, has adopted American test methods and limits (ANSI/BIFMA-M7.1) as reward system for furniture.

Also the new Ecolabel schemes for furniture and wooden floors contain some specifications for VOC emissions.

\section{ORIGIN OF INDOOR EMISSIONS IN THE WOOD AND FURNITURE SECTOR}

VOC emissions from furniture and construction products mainly derive from the coating materials with which they are finished [11].

Nevertheless other materials may contribute to this effect first of all wood and its derivate. It is well known that the various wood species contain different types of organic extractives, some of which are characterized by a certain volatility such as terpenes, certain acids and aldehydes including the same formaldehyde. It is interesting to note, in this regard, that the odour of some softwoods, often considered pleasant, is due to the emission of such natural substances.

Considering the substrate, it shall be mentioned that the heating of wood at high temperature in the production processes of wood based panels or in the case of thermo treated wood [1], determines the formation of volatile substances (e.g. acids, aldehydes) as a consequence of the thermal degradation of some wood components.

With reference to coating materials, it can be summarized that the main factors associated to the final indoor emission of the finished product are the following:

- The amounts and types of solvents present, also as thinners, in the specific coating systems adopted;

- The amounts applied;

- The procedures used for the drying phase: systems, conditions (e.g. temperature, ventilation) and time.
It has to remember that the emissions of solvents are irreversible, thus tending to decrease progressively over time as a function of the conditions in which the material is located, even during storage or shipping.

\subsection{Examples of VOC emissions from coated parquet}

The following are some results of a specific research programme carried out by CATAS [12] on different parquet floorings directly sampled from the market and coated with different coating systems. The goal of this study was to get some information about the emissions derived by the different type of coatings used.

Tests were carried out according the EN ISO 160009 standard. Results are reported in the following Tables.

Table 5. Parquet coated with a solvent based coating system (PU-1)

\begin{tabular}{l|cc}
\hline \multicolumn{1}{c|}{ VOC } & $\begin{array}{c}\text { Concentration } \\
72 \text { hours }\left(\mu \mathrm{g} / \mathrm{m}^{3}\right)\end{array}$ & $\begin{array}{c}\text { Concentration } \\
28 \text { days }\left(\mu \mathrm{g} / \mathrm{m}^{3}\right)\end{array}$ \\
\hline Toluene & 12 & 9 \\
Xylene & 48 & 27 \\
Ethyl benzene & 5 & 4 \\
Butoxy ethanol & 16 & 14 \\
n Butyl acetate & 72 & 34 \\
Methoxy propanol & 40 & 32 \\
acetate & & \\
Ethoxy propanol & 116 & 87 \\
acetate & & 6 \\
Di propylen glycol \\
mono propyl ether
\end{tabular}

Table 6. Parquet coated with water based coatings (WB-1)

\begin{tabular}{l|cc}
\hline \multicolumn{1}{c|}{ VOC } & $\begin{array}{c}\text { Concentration } \\
72 \text { hours }\left(\mu \mathrm{g} / \mathrm{m}^{3}\right)\end{array}$ & $\begin{array}{c}\text { Concentration } \\
28 \text { days }\left(\mu \mathrm{g} / \mathrm{m}^{3}\right)\end{array}$ \\
\hline Aldehydes & 38 & 38 \\
Terpenes & 28 & 28 \\
Acetic acid & 265 & 265 \\
Propandiol & 66 & 66 \\
Acetone & 53 & 53 \\
Diethylene glycol & & 309 \\
monomethyl ether & 309 & 166 \\
Butoxy propanol & 166 & 248 \\
Dietylene glycol & & \\
mono butyl ether & 248 & 28 \\
Dipropylene glycol & & \\
mono methyl ether & 28 & 231 \\
N Methyl & & 11 \\
pyrrolidone & 231 & 196 \\
N Ethyl pyrrolidone & 11 & 42 \\
Benzophenon & 196 & 1.681 \\
Others & 42 & 1.681 \\
Total & & \\
\hline
\end{tabular}


Table 7. Parquet coated with oils (Oil-1)

\begin{tabular}{l|cc}
\hline \multicolumn{1}{c|}{ VOC } & $\begin{array}{c}\text { Concentration } \\
72 \text { hours }\left(\mu \mathrm{g} / \mathrm{m}^{3}\right)\end{array}$ & $\begin{array}{c}\text { Concentration } \\
28 \text { days }\left(\mu \mathrm{g} / \mathrm{m}^{3}\right)\end{array}$ \\
\hline Aldehydes & 85 & 72 \\
Carboxylic acids & 812 & 725 \\
Acetamide & 37 & 22 \\
Acetone & 41 & 32 \\
Toluene & 5 & 3 \\
Others & 7 & 4 \\
Total & 987 & 858 \\
\hline
\end{tabular}

Table 8. Parquet coated with radiation curing coatings (UV-1)

\begin{tabular}{l|cc}
\hline VOC & $\begin{array}{c}\text { Concentration } \\
72 \text { hours }\left(\mu \mathrm{g} / \mathrm{m}^{3}\right)\end{array}$ & $\begin{array}{c}\text { Concentration } \\
28 \text { days }\left(\mu \mathrm{g} / \mathrm{m}^{3}\right)\end{array}$ \\
\hline Aldehydes & 32 & 11 \\
Acetic acid & 84 & 57 \\
Methyl acetate & 37 & 10 \\
Ethyl acetate & 12 & 5 \\
Toluene & 17 & 8 \\
Benzophenone & 3 & 2 \\
Benzaldehyde & 3 & 2 \\
Di methyl hydroxy & 7 & 2 \\
acetophenone & & \\
Aromatic & 27 & 13 \\
hydrocarbons & 15 & 7 \\
Others & 220 & 117 \\
Total & & \\
\hline
\end{tabular}

Table 9. Parquet coated with radiation curing coatings (UV-2)

\begin{tabular}{l|cc}
\hline \multicolumn{1}{c|}{ VOC } & $\begin{array}{c}\text { Concentration } \\
72 \text { hours }\left(\mu \mathrm{g} / \mathrm{m}^{3}\right)\end{array}$ & $\begin{array}{c}\text { Concentration } \\
28 \text { days }\left(\mu \mathrm{g} / \mathrm{m}^{3}\right)\end{array}$ \\
\hline Aldehydes & 2 & 2 \\
Acetic acid & 99 & 70 \\
i-Propanol & 157 & 71 \\
DPGDA & 42 & 13 \\
HDDA & 1.120 & HDDA \\
Benzophenone & 21 & 13 \\
Benzaldehyde & 8 & 2 \\
Di-methyl-hydroxy & 40 & 20 \\
acetophenone & & \\
Hydroxy-cyclohexyl & 63 & 23 \\
phenyl ketone & 88 & 34 \\
Others & 1.640 & 842 \\
Total &
\end{tabular}

(*) Limit derived from the official German list of LCI

\subsection{Data processing}

The data reported above reveal considerable evidences of the subject of indoor emissions which can be summarized in the following points:

- New construction material can emit considerable amounts of organic volatile substance especially immediately after their installation.

- The levels of VOC emissions derived from the data reported above are generally below the limits (see in particular the German and French laws) but close to them in many cases.

- From the qualitative point of view the substances emitted are generally those normally used as solvents in the coating systems typically used: esters, ketones, alcohols, aliphatic hydrocarbons, and aromatic hydrocarbons. Glycol ethers, which are slow evaporating solvents, are mainly present in water-based coatings. In the case of radiation curing coatings (see tables 7 and 8) it can be noted the emission of acrylic monomers or of substances such as benzaldehyde and methyl benzoate resulting from chemical reactions involving some special additives called photo initiators

- A high content of solvents in the liquid coating material is not directly related to a high emission of VOC from the finished product.

- The indoor emissions depend on the VOC present in the liquid coating but the chemical nature is fundamental

- The "natural" treatments are not free from indoor emissions

- The selection of the coating system is important but application rate and drying are also fundamental. Table 9, in particular, reveals a high emission of an acrylic monomer probably due to a deficiency in the UV curing system.

\section{CONCLUSIONS AND POSSIBLE DEPLOYMENTS}

The increasing sensitivity towards indoor emissions is producing a consistent development of laws, standards and voluntary certifications. Such documents are very often characterized by a different approach especially related to the threshold limits.

This situation has been described in the current paper together with some indications of the sources of such emission and indications about their possible control during the production phases.

Notwithstanding the evidence of the complexity of this subject, this paper has reported some of the major reference milestones in order to represent a useful tool for all the market of wood and furniture products.

This aspect of strict VOC emission control assumes an additional relevance considering how new wooden based materials are facing out on the market thanks to their superior properties, offered by unfamiliar chemical compositions and unconventional treatments [13-15]. Regulations, certification and tests have to be developed in accordance with these changes in prospective and offering the highest attention for safety characterizing the modern manufacturing [16].

\section{ACKNOWLEDGMENT}

This investigation was supported by the European Union, IPA Adriatic CBC Program, inside the AdriaHUB project. More details regarding this transnational collaborative action are available in [17]

\section{REFERENCES}

[1] Bulian, F.: Materials and Technologies of the Furniture Industry, Edizioni Goliardiche, 2012.

[2] European Collaborative Action, Report No 27, Harmonisation framework for indoor products labelling schemes in the EU. EU Commission JRC, 2012.

[3] Journal Official de la République Francaise, Arrêté du 19 avril 2011 relatif à l'étiquetage des produits 
de construction ou de revêtement de mur ou de sol et des peintures et vernis sur leurs émissions de polluants volatils.

[4] Health-related Evaluation Procedure for Volatile Organic Compounds Emissions (2008) from Building Products, www.umweltbundesamt.de

[5] Royal Decree establishing threshold levels for the emissions to the indoor environment from construction products for certain intended uses. 2012.

[6] Regulation No 305/2011 of the EU parliament and the Council (2011), Harmonised conditions for the marketing of construction products.

[7] Ikea Specification, (2011) Chemical compounds and substances - IOS MAT 10, IKEA.

[8] Danish Indoor Climate Label (http://www. teknologisk.dk/ydelser/dansk-indeklimamaerkning/253).

[9] Finnish emission classification for building materials (https://www.rakennustieto.fi/index/english/emissio nclassificationofbuildingmaterials.html).

[10] RAL (2011), RAL-UZ 38 Low emission Wood products and wood-Base products. RAL gGmbH.

[11]Bulian, F. and Graystone, J.: Wood Coatings, Theory and Practice, Elsevier, 2009.

[12] Bulian, F.: New Challenges for Wood Coatings, (2013), Proceeding of the 3rd International Conference on Production Engineering and Management, University of Trieste.

[13]Zivkovic, I., Pavlovic, A. and Fragassa, C.: Improvements in wood thermoplastic composite materials properties by physical and chemical treatments. International Journal of Quality Research; Vol. 10, No. 1: pp 205-218, 2016.

[14] Fragassa, C.: Effect of Natural Fibers and BioResins on Mechanical Properties in Hybrid and Non-Hybrid Composites. Proceedings of the 8th Conference on Times of Polymers \& Composites. American Institute of Physics (AIP). 19-23th June 2016, Ischia (Italy). AIP Conference Proceedings 1736, 020118 (2016); doi: 10.1063/1.4949693.

[15] Fotouhi, M., Saghafi, H., Brugo, T., Minak, G., Fragassa, C., Zucchelli A and Ahmadi, M.: Effect of PVDF nanofibers on the fracture behavior of composite laminates for high-speed woodworking machines. Proceedings of the Institution of
Mechanical Engineers, Part C: Journal of Mechanical Engineering Science. 1989-1996 (vols 203-210). May $2016 . \quad$ Doi: 10.1177/0954406216650711

[16] Lucisano, G., Stefanovic, M. and Fragassa, C.: Advanced Design Solutions for High-Precision Woodworking Machines. International Journal of Quality Research; Vol. 10, No. 1: pp 143-158, 2016.

[17] Savoia, M., Stefanovic, M. and Fragassa, C.: Merging Technical Competences and Human Resources with the Aim at Contributing to Transform the Adriatic Area in Stable Hub for a Sustainable Technological Development. International Journal of Quality Research, Vol 10, No. 1, pp. 1-12, 2016.

\section{ЕМИСИЈЕ ИСПАРЉИВИХ ОРГАНСКИХ ЈЕДИЊЕЊА ИЗ ДРВЕНИХ ПРОИЗВОДА И НАМЕШТАЈА: ПРЕГЛЕД ЗАКОНОДАВСТВА, НОРМАТИВА И МЕРА ЗАШТИТЕ ЗА РАЗЛИЧИТЕ МАТЕРИЈАЛЕ}

\section{Ф. Булиан, К. Фрагаса}

На здравље и безбедност људи у унутрашњим просторијама утиче не само клима и биолошки агенси (бактерије, вируси), већ и могуће присуство загађивача ваздуха. Загађивачи могу да долазе из многих извора, као што су дим цигарета, камина, припрема хране, саобраћаја, итд. Чак и намештај и грађевински материјали који се користе у конструкцијама (подови, плафони, зидови, итд) могу да емитују материје штетне по здравље. Такве емисије углавном произилазе из премаза који се примењују на површинама готових производа, па самим тим посебну пажњу треба посветити изради и употреби таквих производа.

Овај рад представља преглед законодавних и нормативних сценарија унутрашњих емисија са доказима о неким подацима из паркетних премаза различитих материјала који се користе за облагања. Рад, као и горе наведени концепти, представљају референтну тачку за све оператере у сектору с обзиром на иновативну природу и јак утицај који емисија испарљивих органских једињења тренутно има у овој области. 